\title{
Correction to: The ethical application of biometric facial recognition technology
}

\author{
Marcus Smith ${ }^{1}$. Seumas Miller ${ }^{2,3,4}$
}

Accepted: 31 May 2021

๑) Springer-Verlag London Ltd., part of Springer Nature 2021

Correction to: Al \& SOCIETY

https://doi.org/10.1007/s00146-021-01199-9

In the original publication of the article, the author Prof. Seumas Miller was missed to be added as the co-corresponding author in the author group. This has been now corrected with this erratum.

The original article has been corrected.

Publisher's Note Springer Nature remains neutral with regard to jurisdictional claims in published maps and institutional affiliations.

The original article can be found online at https://doi.org/10.1007/ s00146-021-01199-9.

Marcus Smith

marcussmith@csu.edu.au

$\triangle$ Seumas Miller

semiller@csu.edu.au

1 Centre for Law and Justice, Charles Sturt University,

Canberra, Australia

2 Australian Graduate School of Policing and Security, Charles Sturt University, Canberra, Australia

3 Delft University of Technology, The Hague, The Netherlands

4 University of Oxford, Oxford, UK 